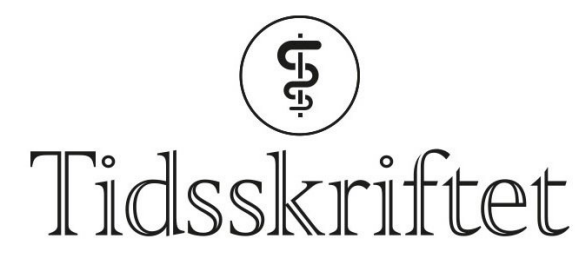

DEN NORSKE LEGEFORENING

\title{
Forside nr. 17/2019
}

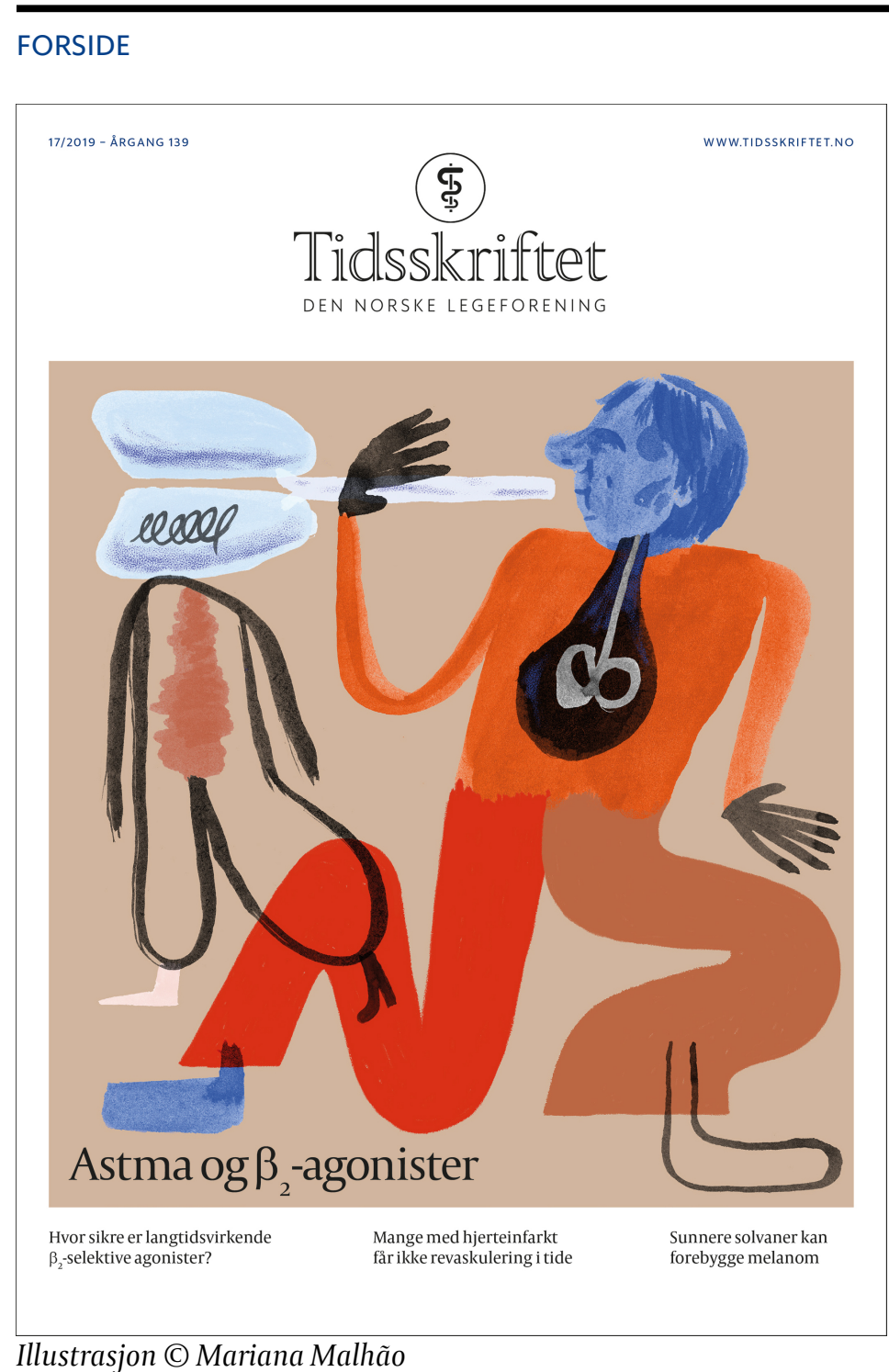

Til behandling av astma benyttes flere ulike medisiner. Blant disse er $\beta_{2}$-agonister til inhalasjon, som har vært assosiert med økt dødelighet siden de ble introdusert i 196o-årene. Fra århundreskiftet har bekymringen primært vært knyttet til de langtidsvirkende $\beta_{2}$ agonistene. I en oversiktsartikkel i denne utgaven av Tidsskriftet presenteres dokumentasjonen ved bruk av slike medikamenter, med fokus på bekymringen om $ø \mathrm{kt}$ dødelighet.

Astma rammer vår evne til å puste fritt. Hindres vår frie respirasjon, kan det utløse angst.

- Så det er ganske forstyrrende å vite at kuren også kan være skadelig, sier kunstner Mariana 
Malhão. Hun bruker slyngede former og kontrast mellom transparente og opake farger for å illustrere luft som strømmer og opplevelsen av angst når luften blir borte. Bildet representerer en ond sirkel av problem og kur. Flere av Malhãos arbeider kan sees på www.marianamalhao.com.

Publisert: 18. november 2019. Tidsskr Nor Legeforen. DOI: 10.4045/tidsskr.19.17.02

(C) Tidsskrift for Den norske legeforening 2020. Lastet ned fra tidsskriftet.no 